\section{No pigs in pokes}

\section{A British dimension to the US Strategic Defense}

Initiative is not necessarily a bad thing.

THE trouble with the Strategic Defense Initiative (SDI) is that it means all things to all men. To Mr Reagan, it ensures immunity from other people's hostile missiles, but to Mr Gorbachev it is an abomination. Mrs Margaret Thatcher, the British Prime Minister, is somewhere in between. Through her, the British government has insisted that SDI is a research programme only, and that there is no question of deployment unless the owners of hostile missiles are consulted. Mrs Thatcher has also taken the lead in Western Europe in saying that influence of this kind requires collaboration, but only if the price is high enough.

How well does last week's agreement between the defence ministers of Britain and the United States match these good resolutions? Nobody can be sure. Virtually the only provision of the document made public is that which specifies that the substance of the agreement will be kept secret "in perpetuity". There will never be an opportunity for telling what costs, and what prizes the participants can expect. For all that can be told, the agreement may consist only of a single sheet of paper binding the participants merely to declare they have agreed to collaborate on SDI, but saying nothing else (together with the bit about perpetuity). So what should such an agreement contain? Even those who believe that Britain should not take part have an interest that the agreement should be equitable.

Technically, there are several important issues, of which the chief is whether SDI will be a stimulus to economic innovation. The argument is simple, but also simplistic. Spend money on military innovation, and you cannot fail to generate economically worthwhile innovations. So the more technical effort in British defence laboratories, the more prosperous British civil industry will become. There are two obvious objections. First, Japan, the most successful source of economic innovation, supports only a small military establishment. Second, Britain has for four decades spent conspicuously on defence research, but has been woefully inadequate at converting military into civil innovations. Whatever the secrets of last week's agreement, there is no chance that economic benefits will flow without structural changes in the relationship between military and civil research.

Worse, in British (but not American) conditions, the involvement of industry with powerful customers for knowledge (as SDI will be) can have the opposite effect; in retrospect, the dependence of the British telecommunications industry on the old public monopoly of British Telecom, far from making it competitive with free-standing industries elsewhere, actually made it harder for British companies to hold their own in world markets. At this stage, arguments about proprietary rights to inventions are academic.

So the long-term commercial benefits to Britain cannot be large unless there is structural change. Will the short-term cash (there has been talk of British organizations winning 7 per cent of the total) be of assistance? Here again, the arithmetic is clouded. If there is more money, some who might have emigrated may stay in Britain; the other side of that coin is that close acquaintance with SDI may tempt others who would have stayed in Britain to cross the Atlantic. But the most likely (and sombre) course of events is that great skill will be locked up in a programme of little economic value. The chances that people will pick up skills they never had, and will afterwards deploy them in civil applications, are small.

Technically, SDI is more likely to be a diversion than an opportunity. Politically, given the point from which the British government starts on strategic issues, it is on more sure ground. At some stage, there is bound to be an argument about the rights and wrongs of deployment. Most probably, if SDI yields anything of value to military technology (early warning is probably inevitable), there will be pressures to deploy what machines there are before the other side has been consulted. That is when
Mrs Thatcher or her political heirs will be able to cash the political cheques they will earn in the next few years. The question, and perhaps the darkest cloud over last week's agreement, is whether British governments will keep their independence and their nerve over the whole decade ahead.

\section{Australia's grudge}

\section{The McLelland report seems a fair complaint.} What can be done?

THAT Australia should have been up in arms about the uses made by the British government of the deserts of Western Australia for testing British bombs three decades ago is natural and understandable. Last week's report on more than two years of a judicial investigation of the matter (strictly by a Royal Commission set up by the government of Australia) has failed to substantiate the more lurid tales told in evidence, but is otherwise fair. The chief recommendation, that the British government should somehow compensate Australia for the damage done, perhaps by cleaning up the radioactive mess left behind, is on the face of things a reasonable demand. But there is a danger that relations between the two governments will deteriorate into an unseemly squabble unless both of them acknowledge how much has changed, technically and in their political relations with each other, since the days when the Prime Minister of Australia, Sir Robert Menzies, was one of Sir Winston Churchill's closest buddies.

With the lapse of thirty years, it is hard fully to appreciate that even technical people could have been as naive as those in charge of the early nuclear tests about the dangers of radioactivity, both ionizing radiation produced directly from exploding fireballs and radioactive fission products or other radioactive isotopes produced indirectly, by the irradiation of material in the environment. To be sure, by 1945 there was a growing body of knowledge of the problems. The effects of $X$ rays had been carefully studied, while the Manhattan project had thrown up a substantial understanding of the effects of external radiation by other materials, neutrons for example. The destruction of Hiroshima and Nagasaki eventually yielded crucial data about the biological effects of acute doses of external radiation. But of necessity, the effects of small doses (sustained by people some distance from the explosions) accumulated only as the years went by. So, by the time of the United States conference on the Peaceful Uses of Atomic Energy exactly thirty years ago, it was possible for the then chairman of the then US Atomic Energy Commission, $\mathrm{Mr}$ Lewis Strauss, to insist that there must be some kind of threshold dose of radiation below which no biological damage would be done. While Mr Strauss may have had a special flair for resisting unwelcome ideas, he was by no means untypical of those with influence in the 1950s. And only about that time did even the critics of nuclear weapons testing begin to accumulate telling evidence of the kind that eventually brought tests of nuclear weapons in the atmosphere to a halt.

The other important change that has come about in the past thirty years concerns Britain and Australia, then bound together both by the warm sense of having worked successfully together in a good cause (the Second World War) and, less easily, by the old ties of empire. It is hard now to reconstruct the familiarity of that relationship, although it seemed as natural to many Australians as it seems to have done to Menzies that the British should have been given more or less free range of the testing grounds in Australia. That the use they made of their licence may have been, by present standards, imprudent is amply demonstrated by last week's report. Much the same was happening then and earlier at the US testing grounds in the Pacific (see p. 502). The most urgent need now is that the British government should openly acknowledge the likelihood that much of Judge McLelland's argument is correct. To do that need be no shame (nor entail the $\mathbf{A} \$ 100$ million talked of). To fail to make proper acknowledgement would be unjust, and make still more distant the relationship between Britain and Australia. 